\title{
Prevalance and Intensity of Helminthiasis in Gastrointestinal Tractus of Goat At Kwanyar Sub-District, Bangkalan District
}

\author{
${ }^{1)}$ Alivia Fairuz Ilmi, ${ }^{2)}$ Arimbi, ${ }^{2}$ Sarmanu, ${ }^{4}$ Agus Wijaya \\ ${ }^{1)}$ Student, Faculty of Veterinary Medicine, Universitas Airlangga, fairuzalivia@gmail.com \\ ${ }^{2)}$ Division of Veterinary Pathology, Faculty of Veterinary Medicine, Universitas Airlangga \\ ${ }^{3}$ Division of Veterinary Anatomy, Faculty of Veterinary Medicine, Universitas Airlangga \\ ${ }^{4)}$ Veterinary Internal Medicine Division, Department of Clinic, Reproduction and Pathology, Faculty of \\ Veterinary Medicine, IPB University \\ Corresponding author: arimbi@fkh.unair.ac.id
}

\begin{abstract}
This study aims to determine the prevalence and intensity of helminthiasis in gastrointestinal tract of goat at Kwanyar Sub-District, Bangkalan District. The study was conducted in August-October 2018 with 100 samples of stool examination in the laboratory of Helmintology, Division of Veterinary Parasitology, Faculty of Veterinary Medicine, Universitas Airlangga. The results were found various worm eggs such as Oesophagustomum sp., Strongyloides sp., Haemonchus sp., Trichuris sp., and Chabertia sp. Moreover, the prevalence of gastrointestinal helminthiasis was recorded at $100 \%$. In addition, the calculation of worm eggs per gram fecal sample was obtained the number of infecting eggs ranges from $\mathbf{0}^{-500}$ and the categorized as mild degree of infection. The results of statistical analysis using Chi-Square test was showed no significant differences in the intensity of infection in male and female goats ( $p>0.05$ ). However, there was significant differences in the intensity of infection in goat between $0-12$ months age and above 12 months age $(\mathrm{p}<0.05)$.
\end{abstract}

Keywords : gastrointestinal, goat, helminthiasis, intensity, prevalence, Bangkalan.

\section{Introduction}

Kwanyar sub-district is one of the SubDistricts in Bangkalan District. Most of the individual population raise livestock such as cattles, goats, and chickens. The calculated population of 4,112 goats indicates the number of people who raise goats especially in Kwanyar sub-istrict (East Java Province Livestock Service, 2016).

Based on direct field observation, the majority of goats in there were looks thin, both young and adults. The cage management system in Kwanyar Sub-District is still using traditional method. The goats were fed with fresh grass without drying it first and the construction of the cage is made from bamboo and it is located in the open field without any drainage system for feces, urine and a lot of leftover feed so that the sanitation method is not maintained properly. This phenomenon can be associated with the helminthiasis cases and become the most potential risk factors.

One of the main obstacle that faced by goat and sheep breeders is parasitic disease that potentially inhibits ruminants growth and lead to weight loss (Bahri et al., 2008). Parasite worm infections in goat is rarely causing death, but this disease categorized as chronic so that in adult goats it has an impact on decreasing milk production and meat quality, while in young goats it can cause stunted growth, decreased appetite, anemia, diarrhea, and dehydration (Soulsby, 1986). Previous study which conducted by Suhardono et al. (2012) was found that helminthiasis infection in goats recorded very high in prevalence rate at $100 \%$.

Helminthiasis cases of the digestive tract that often occur are caused by various factors including the quality of the cage management, sanitation, goat density, temperature, humidity and vegetation (Egido et al., 2001). Intrinsic factors from the livestock body also affect the sensitivity of animals to helminth infections, including animal species, age, sex and immunity. The resistance mechanism to parasite worm infection is also influenced by the age factor, where the immune reaction in adult animals is better than young animals (Raza et al., 2012). Female animals have high antibodies so that they are more resistant to gastrointestinal 
helminthiasis compared than male animals (Amaral et al., 2001).

Based on its geographical location, parasitic worms can survive in tropical climates with an average rainfall of $250 \mathrm{~mm}$ per year (Subekti et al., 2013). Geographically, the location of Kwanyar Sub-District, Bangkalan District, categorized as areas near the coast with high temperature and humidity conditions, so that potentially become source of worm infections in goats. To our knowledge, there is no data regarding helminthiasis cases in Kwanyar Sub-District, Bangkalan District. Therefore, this study was conducted to determine the prevalence and intensity of helminthiasis infection in goats so that the results can be applied in disease control measure especially in goat which naturally infected with gastrointestinal helminthiasis.

\section{Materials and Methods}

Samples were taken from 100 fresh goat feces from Kwanyar Sub-District, Bangkalan District. The detection and examination of helminth infection were done by observation with native, sedimentation, and floating of feces. For calculating Egg Per Gram (EPG) used method of Lucient Brumpt.

The results obtained from the prevalence rate and Egg Per Gram (EPG) method of Lucient
Brumpt were analyzed by Chi square test using the Statistical Product and Science Solution (SPSS) version 24 for windows program, in order to determine the difference in prevalence and intensity of helminthiasis infection in male and female goats as well as in goats o-12 months age andvi2 months above.

\section{Results and Discussion}

The prevalence of gastrointestinal helminthiasis in goat

Based on the examination of 100 goat fecal samples, which divided into 53 male and 47 female goats in Kwanyar Sub-District, Bangkalan District, the prevalence rate was recorded at $100 \%$. Various types of worm eggs, were also detected in present study and the details were presented in Table 1 and Figure 1.

Table 1. Parasite worm eggs which detected in goat fecal sample at Kwanyar Sub-District, Bangkalan District.

\begin{tabular}{lc}
\hline Parasitic Worm & Total \\
\hline Haemonchus sp. & 51 \\
Trichuris sp. & 45 \\
Oesophagostomum sp. & 32 \\
Strongiloides sp. & 8 \\
Chabertia sp. & 3 \\
\hline
\end{tabular}
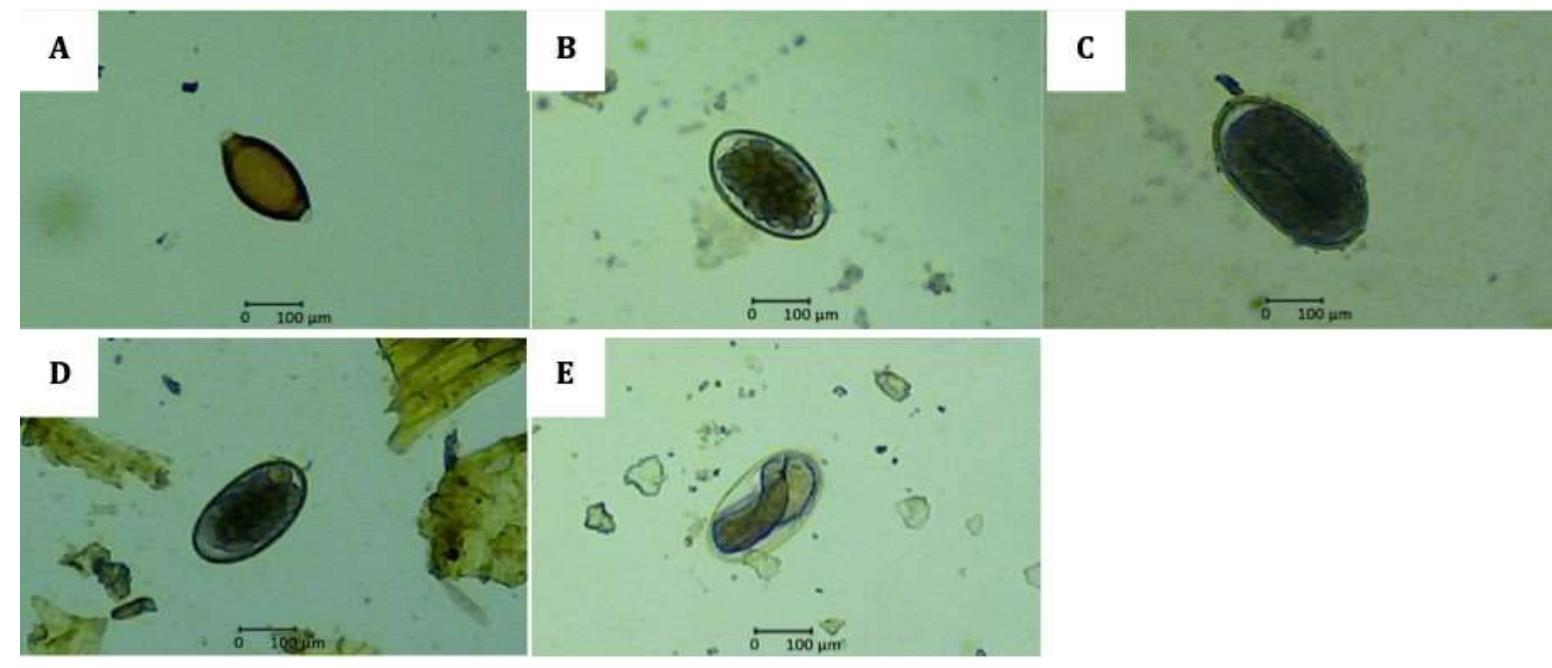

Figure 1. Parasite worm eggs which naturally infecting goat at Kwanyar Sub-District, Bangkalan District. A. Trichuris sp., B. Haemonchus sp., C. Chabertia sp., D. Oesophagostomum sp., E. Strongyloides sp. 
Table 2. Parasite worm eggs which detected in goat fecal sample based on sex and age group at Kwanyar Sub-District, Bangkalan District.

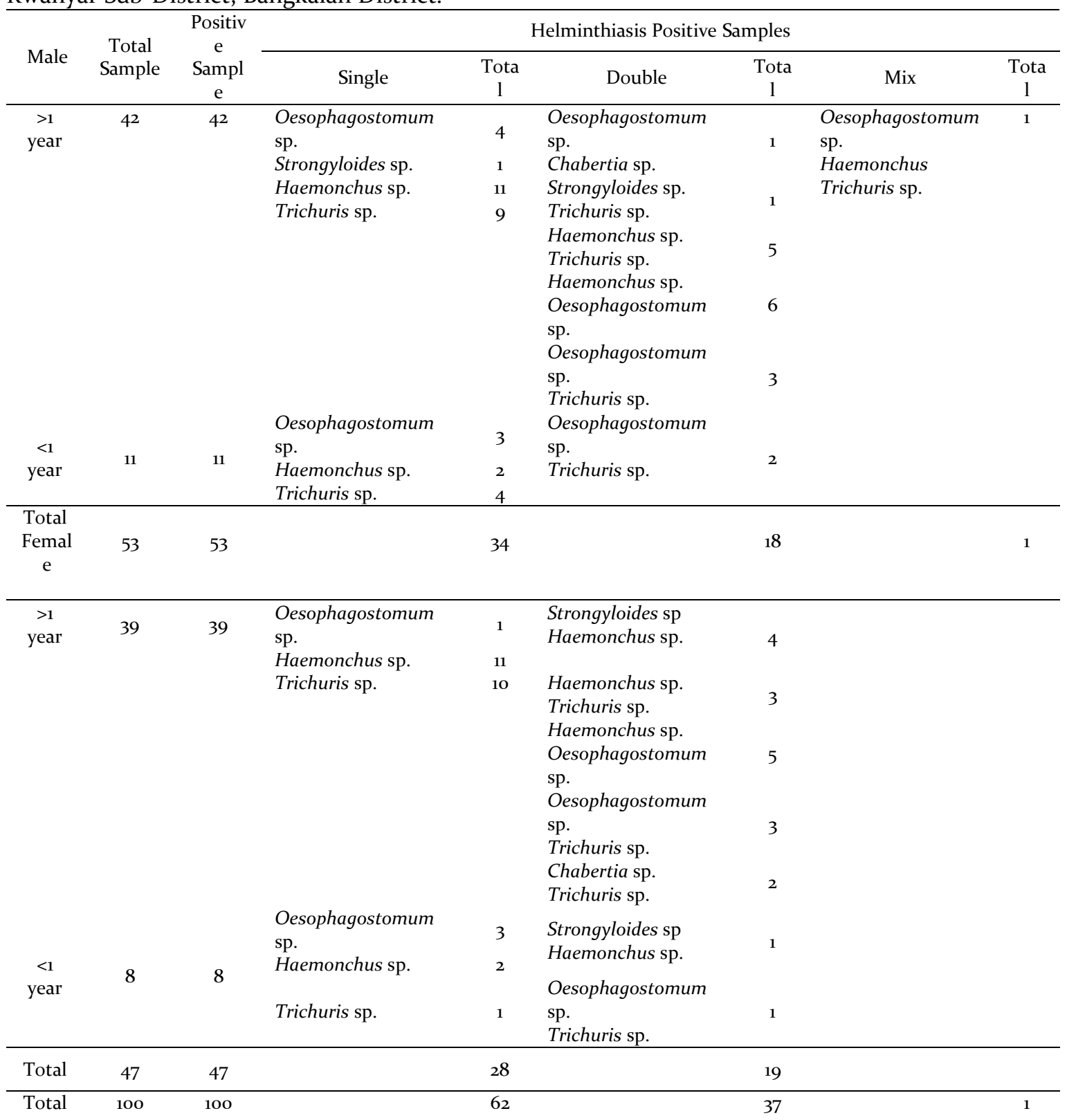

Fecal samples which identified as single or mixed infection gastrointestinal helminthiasis during present study were recorded in Table 2.

The high prevalence of gastrointestinal helminthiasis in goats at Kwanyar Sub-District, Bangkalan District is possibly due to the traditional management system with goat cages placed in the open field without any faecal and urine disposal channels and a lot of leftover feed which not cleaned properly so that the cage sanitation is not well applied. The amount of feces and food residue that accumulates in the cage can be one of the factors regarding the high prevalence of helminthiasis in the digestive tractus. Dirt accumulated around the cage will increase the temperature and humidity level. Purwanta et al. (2006) states that a humid environment is a suitable condition for the growth of various types of parasitic worms, in order to complete their life cycle. Sampling was carried out in August, in that month Kwanyar Sub-District had the highest average of daily rainfall (125 mm/day) during 2018 (Central Bureau of Statistics Bangkalan District, 2018), this can be a factor which related to the high prevalence of gastrointestinal helminthiasis in goat. The higher infection rate in wet season may also be associated with the corresponding molarity of salt in the soil which also an important factor for the ecdysis process in 
parasitic worms (Soulsby, 1986). The results of present study are in accordance with Singh et al. (2017) who conducted study in Punjab, India and recorded that the highest prevalence of gastrointestinal parasites in goats occurs slightly in the rainy season $(90.10 \%)$ followed by winter and then summer. Provision of forage without the withering process can also be a risk factor in the high prevalence of gastrointestinal helminthiasis recorded in goat, because the worm eggs attach to fresh grass which makes parasites can spread and infect other goats (Subekti et al., 2013).

All of parasite worms found in this study were from the Nematoda class, this is presumably because the goats in Kwanyar SubDistrict, Bangkalan District were given feed in the form of grass taken in pastures where ruminants were being grazed. The condition of pastures that do not have stagnant water, and not categorized as rice field area is causing the absence of parasitic worms from the Trematoda and Cestoda classes that require mostly freshwater snails as intermediate host (Subekti et al., 2010).

The most common infection in goats was caused by Haemonchus sp. Blood and Radostits (1989) states that Haemonchus sp. was often found in goats, presumably because the larvae of Haemonchus sp. worm can incubate up to 10,000 eggs per day (Soulsby, 1986) making it possible for more transmission with a higher rate compared than the other parasite worms.

Fertile and hot grasslands, and a humid climate are ideal conditions for reproduction of Haemonchus sp. outside the digestive tractus of livestock. The optimum ambient temperature for $H$. contortus is $18^{\circ} \mathrm{C}-26^{\circ} \mathrm{C}$. High humidity more than $85 \%$ is important for parasite growth because the large amount of moisture in the air helps protect parasites from drying out at high temperatures (Urquhat et al., 1996). The location of Kwanyar Sub-District, Bangkalan District is an area near the coast with high temperature and humidity conditions, making a suitable condition for the transmission of $H$. contortus worm infection.

These results are in accordance with previous study which conducted by Das et al. (2017) in Meghalaya, India using 834 fecal samples, the prevalence rate of $H$. contortus was recorded as the highest $(72.16 \%)$. The results of the examination carried out by Hurriyyah (2017) obtained 23 positive samples containing Nematoda worm eggs from 42 goat fecal samples in Turi Sub-District, Lamongan District. The species that infects the most was $H$. contortus recorded at $60.87 \%$ followed by Strongyloides papillosus at $39.13 \%$.

The second most common infection was dominated by Trichuris sp. worms, which detected from 45 samples with details of 24 single infections and 21 mixed infection. This is presumably because the eggs of Trichuris sp. had a thick sheath that is resistant to drought or wetness condition so that it can last for four to five years in pastures (Subekti et al., 2013).

The third most common infection was dominated by Oesophagostomum sp., which detected from 21 samples followed by Strongyloides sp. detected from 7 samples and Chabertia sp. from 3 positive fecal samples. Theoretically, the larvae of this worm can infect livestock in cages or even perform autoinfection because the worm eggs already contain larvae and hatched very quickly. The source of transmission is possibly come from grass feed which taken from fields or gardens where ruminants often grazed. The grass has been infested by infective larvae that tend to lie on the ground or under the damp grass (Purwaningsih et al., 2017).

\section{The intensity of gastrointestinal helmin- thiasis infection in goat}

The results of worm Eggs Per Gram (EPG) examination analyze using Chi square test on male and female goats obtained a significance value of 0.549 which showed no significant difference ( $>>0.05)$. The data shows that both male and female goats have the same opportunity to be infected with gastrointestinal worms. The results of analysis was showed that there was no significant difference in the intensity of worm infection in the digestive tract of male and female goats, because male and female goats were kept in the same cage, with the same cage conditions, maintenance and feeding methods, so that the comparison of resistance to infection between male and female goats were not significantly different (Purwaningsih et al., 2017).

The results of statistical analysis using $2 \times 2$ cross tabulation was showed that $11.33 \%$ male goats had more moderate infection compared than female goats, which had $6.39 \%$ moderate infection. This is because female goats have higher levels of the estrogen hormone, so they can stimulate reticulo endothelial cells to form antibodies against 
parasites (Suweta, 1985). The results of the cross tabulation comparison of the intensity of infection between male and female goat can be seen in Table 3 .

Table 3. The results of comparison in the intensity of infection between male and female goat.

\begin{tabular}{lccc}
\hline \multirow{2}{*}{ Sex } & \multicolumn{2}{c}{$\begin{array}{c}\text { Intensity of } \\
\text { infection }\end{array}$} & Total \\
\cline { 2 - 3 } & Mild & Moderate & \\
\hline Male & 88.67 & 11.33 & 53 \\
Female & 93.61 & 6.39 & 47 \\
\hline Total & & & 100
\end{tabular}

The results of EPG comparison analysis using the Chi square test on goats aged 1-12 months and aged above 12 months obtained a significance value of 0.000 which indicates there was a significant difference $(\mathrm{p}<0.05)$. The results of statistical analysis using $2 \times 2$ cross tabulation showed that $9.88 \%$ of goats aged above 12 months had a moderate degree of infection compared than goats aged 1-12 months, which had a moderate degree of infection at $5.25 \%$. The results of the cross tabulation comparison of the intensity of infection based on age group can be seen in Table 4.

Table 4. The results of comparison in the intensity of infection based on different age group.

\begin{tabular}{lccc}
\hline \multirow{2}{*}{ Sex } & \multicolumn{2}{c}{$\begin{array}{c}\text { Intensity of } \\
\text { infection }\end{array}$} & Total \\
\cline { 2 - 3 } & Mild & Moderate & \\
\hline $\begin{array}{l}\text { 1-12 } \\
\text { months }\end{array}$ & 94.73 & 5.35 & 19 \\
$\begin{array}{l}>12 \\
\text { months }\end{array}$ & 90.12 & 9.88 & 81 \\
\hline Total & & & 100
\end{tabular}

This is thought to be influenced by the instability of immunity due to pregnancy, childbirth, and lactation period which can worsen the condition so that the occurrence of helminthiasis in livestock slightly increase. In addition, adult goats are generally kept longer as broodstock so that the risk of exposure to worms will also be longer. Levine (1990) states that natural infection in animals occurs by ingesting larvae day by day for a long period. Meanwhile, in young goats the immunity comes from their mother's milk.
Moreover, the frequency and volume of the entry of grass into the digestive tract of young goats is not as frequent and as much as adult goats (Mukti et al., 2016).

\section{Conclusions}

The prevalence of gastrointestinal helminthiasis in goats at Kwanyar SubDistrict, Bangkalan District was recorded at $100 \%$ with several types of parasite worms successfully identified such Haemonchus sp., Trichuris sp., Oesophagustomum sp., Strongyloides sp. and Chabertia sp. Chi Square analysis showed that the intensity of gastrointestinal helminthiasis infection was not significantly different between males and females group. However, in the age group 0-12 months and above 12 months it was recorded significantly different.

\section{References}

Amaral, A.C., J.D.C. Freitas., and A.M.D.C.G Noronha. 2016. Prevalence of Round Worm (Toxocara vitolorum) in Balinese Cattle Calves in the Western Region of Timor Leste. Timor Leste Studies Association. 1: 149-151.

Badan Pusat Statistik Kabupaten Bangkalan. 2018. Kecamatan Kwanyar Dalam Angka 2018.//www.disnak.jatimprov.go.id/.

Bahri, S., R.M.A. Adjid., Beriajaya dan A.H. Wardhana. 20o8. Manajemen Ternak Kambing. Lokakarya Nasional Kambing Potong, Hal 79.

Blood, D.C. and O.M. Radosists. 1989. Veterinary Medicine. $7^{\text {th }}$ ed. The English Language Book Socienty and Bailliere Tindall. London. 764.

Das, M., R. Laha, A. Goswami, and A. Sen. 2017. Gastrointestinal Parasitism of Goats in Hilly Region of Meghalaya, India. Vet. World. 10(1):81-85.

Dinas Peternakan Provinsi Jawa Timur. 2016. Data Statistik Populasi Ternak. www. disnak. jatimprov.go.id/.

Egido, J.M., J.A. De Diego and P. Penin. 2001. The Prevalence of Enteropathy due to Strongyloidiasis in Puerto Maldonado (Peruvian Amazon). Braz J Infect Dis. 5:119-123. 
Hurriyyah, Z. 2017. Hubungan Antara Jenis Telur Cacing Saluran Pencernaan dan Derajat Keparahan dengan Manajemen Pemeliharaan Kambing di Desa Turi Kecamatan Turi Kabupaten Lamongan. Universitas Airlangga. Surabaya.

Levine, N.D. 199o. Buku Pelajaran Parasitologi Veteriner. Gadjah Mada University Press. Yogyakarta. Hal 383-396.
Mukti, T., I.B.M. Oka, dan I.M. Dwinata. 2014. Prevalensi Cacing Nematoda Saluran Pencernaan pada Kambiing Peranakan Ettawa di Kecamatan Siliragung, Kabupaten Banyuwangi, Jawa Timur. Indonesia Medicus Veteriner. 5(4):330336 